\title{
Case Commentaries
}

\author{
Equal Protection for Non-English-Speaking \\ School Children: Lau v. Nichols
}

\author{
Stephen D. Sugarman* \\ and Ellen G. Widess**
}

[On January 21, 1974, while this Commentary was in page proofs, the United States Suprene Court unanimously reversed the Ninth Circuit's decision and renianded the case to the district court for appropriate relief. The Court did not reach the equal protection issue emphasized in this Commentary, but rather based its holding on the Civil Rights Act of 1964 which is discussed at pages 16869 infra. Surprisingly, the Court did not deal with the difficult issues of statutory interpretation raised by the Civil Rights Act claim. The Court's statutory approach does, in many respects, parallel the equal protection analysis set out below.]

In Lau v. Nichols, ${ }^{1}$ suit was brought on behalf of eighteen hundred Chinese-American students attending San Francisco public schools. Their complaint is that they are being denied educational opportunity because they do not speak English. At issue is the constitutional right of all non-English-speaking school children to a meaningful public education. For the United States Supreme Court, which is expected to decide the case im its 1973 term, Lau poses troublesome questions of both educational policy and equal protection analysis. A result favorable to the plaintiffs will require a substantial change in the way school districts customarily treat non-English-speaking children and could bring about an improvement in the schooling of milhons of pupils. ${ }^{2}$ At the saine time, such a result will be viewed as further judicial intrusion into local educational policy-making. A decision against the plaintiffs, on the other hand, will be viewed as a retreat

$\ddagger 483$ F.2d 791 (9th Cir. 1973).

The Childhood and Government Project at the University of California, Berkeley, filed an amicus curiae brief in the United States Suprenre Court in connection with the case discussed herein. This Commentary grew out of the authors' work on that brief.

* Acting Professor of Law, University of California, Berkeley. B.S.B.A., 1964; J.D., 1967, Northwestern University.

* Mernber of the Third Year Class, Boalt Hall School of Law. A.B. 1969, University of California, Berkeley.

1. 483 F.2d 791 (9th Cir. 1973), cert. granted, 93 S. Ct. 2786 (1973).

2. It has been estimated that approximately four million children in the nation face the sante problent as plaintiffs in Lau. See generally U.S. DePT. OF HeaLth, 
from the commitment to equal educational opportunity for minority children that the Court has vigorously pressed during the past twenty years of legal battles over school segregation.

In the past, in order to oversee the dismantling of racially dual school systems, the Court has been willing to place the federal judiciary in a supervisory role with regard to local pupil-assignment policies. The Court has also affirmed the obhigation of the federal judiciary to review im-school regulation of student behavior im order to protect the right of children to freedom of expression. However, in Brown $v$. Board of Education ${ }^{3}$ the Court was concerned with who is allowed in the schoolhouse; in Lau the Court is being asked to regulate what goes on inside. In Tinker v. Des Moines Board of Education ${ }^{4}$ the Court decided there are some things a school cannot do to its students; in Lau the Court is being asked to tell the school that there are some things it inust do for its students.

\section{THE ISSUE}

The core of plaintiffs' complaint in Lau is that they do not receive a meaningful education when they are taught in a language they do not understand. ${ }^{5}$ As they see it, they could be taught to speak English, or taught in Chinese until they learned Enghish on their own, or taught in both languages. Instead, they find themselves assigned to classes which are conducted as though every student spoke English. In view of this "Enghish-only" practice, they assert, they are not learning what children are supposed to learn in school.

Education and Welfare (Office of Education), Draft: Five Year Plan 19721977: Bilingual Education Programs, Appendx B (1971). See also Hearings on S. 428 Before the Special Subcomm. on Bilingual Education of the Senate Comm. on Labor and Pub. Welfare, 90 Cong., 1st Sess. ser. 18, pt. 1, at 51-55 (1967). See also Montoya, Bilingual-Bicultural Education: Making Equal Educational Opportunities Available to National Origin Children, 61 Geo. L.J. 991, 992 (1973).

For a thorough discussion of the extent of this problem and the legal issues involved, see Grubb, The Right to Bilingual Education, 9 Harv. Civ. RIGHTs-Civ. Lib. L.R. (1973).

3. 347 U.S. 483 (1954).

4. 393 U.S. 503 (1969). In Tinker, the Court upheld the right of students to wear black armbands at school in protest of the Vietuam War.

5. Plaintiffs' original petition to the U.S. District Court for the Northern District of California (Civ. No. 70 627, filed March 25, 1970) included two classes of non-English-speaking Chinese pupils. The first class was composed of 1,790 Chinesespeaking students in the San Francisco School District who admittedly need special help in English instruction and who receive no help at all. The second class consisted of 1,066 Chinese-speaking pupils who receive some, but allegedly inadequate, assistance. The petition for certiorari to the U.S. Supreme Court (filed April 9, 1973) pursued only the claims of the fornter class, i.e., those pupils receiving no Englisli instruction. Hereinafter "plaintiffs" refers to that class of students receiving no assistance. 
The plight of these children is the product of an historic pattern of isolation of the Chinese. For years governmental policies and legislation excluded members of this race from the mainstream of American life. While blatant governmental racism may be argued to be a thing of the past, the effects of official discrimination are only slowly eliminated. In San Francisco, most Chinese immigrants first settle in Chinatown, a crowded, impoverished, and Chinese-speaking ghetto, ${ }^{7}$ and large numbers of Chinese-Americans remain trapped there. Many never learn to speak English. Although the bulk of San Francisco's Chinese-Americans now hive outside the core of Chinatown, among these are many families wlio are characteristically poor and non-English speaking.

Plaintiffs in Lau represent only the tip of the iceberg. There are huge numbers of children in this country whose families are poor,

6. See generally G. BARTH: BITTER STRENGTH: A HISTORY OF THE CHINESE IN THE U.S., 1850-1870 (1971); H. IsaAcs, Scratches ON OUR Minds (1958); C. Wollenberg, Ethinic Conflict IN California History (1970).

The California Constitution of 1879 explicitly excluded "natives of China" from voting [Art. II, \& 1], and prohibited the employment of Chinese persons by State and local governments and corporations [Art. XIX, §§ 2-4]. Later, an English-literacy voting requirement was enacted by the California legislature to exclude Americanborn children of Chinese immigrants. See Castro v. State, 2 Cal. 3d 223, 230 n.11 (1972). Until as recently as 1947, state legislation authorized the establishment of "Separate schools ... for children of Chinese, Japanese, or Mongolian parentage." CaL. Educ. Code $\$ 8003$ (West, 1943). Pursuant to this legislation, San Francisco established separate schools for Chinese-origin children. See Wong Him v. Callahan, 119 F. 381 (C.C.N.D. Cal. 1902). See also Gong Lum v. Rice, 275 U.S. 78 (1927), which involved the power of the state to classify children of a "Chinese citizen of the U.S." as among the colored races and exclude them from the public schools maintained for white children.

See generally Guey Heung Lee v. Johnson, 404 U.S. 1215 (Douglas, Circuit Justice, 1971); Yu Cong Eng v. Trinidad, 271 U.S. 500 (1926); Yick Wo v. Hopkins, 118 U.S. 356 (1886).

7. See U.S. Burgau of the Census, Dept. of Commerce, 1970 Census of Population and Housing: Census Tracts, S.F.-Oakland, Calif., Standard Metropolitan Statistical Area, Pub. No. PHC(1)-189 (1972).

The core of Chinatown is described by the boundaries of census tracts, \#114 and \# 118. It is estimated that Chinese-Americans comprise $90 \%$ of the population of these two tracts. Some relevant data for those two tracts are:

(1) Median income of families: Tract \# $114=\$ 5,597$, Tract \# $118=$

$\$ 6,352$, Aggregate of both tracts $=\$ 5,794$, San Francisco as a whole $=$ $\$ 10,503$.

(2) Percent of families below poverty level: Tract \# $114=19.5 \%$, Tract $\# 118=27.6 \%$, Aggregate of both tracts $=21.6 \%$, S.F. as a whole $=9.8 \%$.

(3) Median school years completed by persons 25 or over: Tract \# $114=$ 5.2, Tract \# $118=5.9$, Aggregate of both tracts = 5.6, S.F. as a whole $=12.4$.

(4) Percent of persons 25 years or over who are high school graduates; Tract \# $114=19.2 \%$, Tract $118=24.8 \%$, Aggregate of both tracts $=20.9 \%$, S.F. as a whole $=61.8 \%$.

See Petitioner's Brief for Certiorari at A-105-14, Lan v, Nichols, 93 S. Ct. 2786 (1973). 
whose home language is not English, and who do not speak English at the time they enter public school. While these children come from many different minority groups, they share a common burden: fluency in only a foreign language. Many of them hive in well-known urban, ethnic enclaves such as Harlem (Puerto Rican) and East Los Angeles (Mexican-American). Others are isolated in rural areas, particularly in the Southwest. The home language of most is Spanish. By no means are all of these children ignored by their schools; the apparent success of some existing bilmgual and English-as-a-Second-Language (ESL) programs offered by some schools accentuates the plight of those who are not helped. Indeed, even in San Francisco, there are dual language programs for some Chinese-speaking children.

In a large number of cases, the parents of non-English-speaking children are recent immigrants. Many, however, have lived in America for years (and some, all of their lives) but have not learned to speak Enghish. While the reasons for this are complex, there is one common pattern. Poor non-Enghish-speaking people often live and work together in identifiable racial or ethnic communities, particularly when they belong to a group that has been subjected to discrimination and exclusion from the political, social, and economic processes of this country. In these commumities, native language becomes one source of racial or ethnic unity; it is used on the job, im the streets, and at home. Non-English-speaking people thus remain foreiguers in their own land. In part because of their own lack of education and opportunity, it is often difficult for non-Enghish-speaking parents to help their chilren break out of a life of ethnic exclusion and attendant poverty. They look to the public schools to provide their children a first and essential step toward independence.

As the plaintiffs in Lau view it, however, the schools they are compelled to attend are not places of education or opportumity. They are put in classes where most of the children do speak English. The teachers, who speak only English, have been given no training in how to commumicate with non-Enghish-speaking children. As a result, even if the motives of the classroom teachers are bemign, these children are effectively excluded from participation in the school's educational prograin. At the beginning they mevitably fail to learn the material being taught. Some, lucky enough to begin picking up some English on their own, progress academically, but much more slowly than their English-speaking classmates. From the first, then, non-English-speaking students are doomed to poor achievement, illiteracy, and disproportionately high dropout rates. Often the schools ensure such outcomes through policies which assign non-English-speaking children to classes for the mentally retarded or tracks for the less imtelligent, or force children to repeat grades without making the repeated programming 
any more comprehensible. ${ }^{8}$ The lower expectations of many teachers for these students become self-fulfilling prophecies.

Beyond academic effects, this failure to integrate non-Englishspeaking children into the educational programs of the school is argued to have harmful psychological, economic, and political effects: Children who cannot speak or understand English are stigmatized and made to feel inferior. Their inability to speak the approved language becomes a mark of disgrace. The child internalizes this treatment and takes on a sense of shame for his inadequacy, which in turn reinforces his diminished perception of self-worth. Since scliool credentials are important in the labor market, the way the school has chosen to treat non-English-speaking children also affects their ability to get work. Regarded as qualified only for menial jobs, or no job at all, many of these children will remaim poor and isolated from mainstream American society. In addition, if they never learn to speak English well, their ability to vote, to exercise their free speech riglts, and otherwise to participate in the political process will be severely hampered.

To non-English-speaking children and their advocates, it is bitterly iromic that the very place which ought to help children overcome their "handicap" of ancestry operates instead to injure them. Hence, the plaintiffs in Lau seek a judgment requiring the school district to stop excluding thein froin its educational program, and ordering it to take affirmative steps to provide them with a meaningful educational program. They have not specified what those affirmative steps must be. Instead, they are seeking to employ the judicial process in a manner similar to that typically used in the school segregation area, where defendants are often ordered to prepare plans for the approval of the district court. Thus far, the Lau plaintiffs lave been denied relief in both the District Court for the Northern District of California and the Court of Appeals for the Ninth Circuit.

\section{II}

\section{Setting the Equal Protection Stage}

The principal legal argument of plaintiffs in Lau is that the San Francisco school district's "Enghisl1-only" policy denies them equal protection of the laws. The district court and the Ninth Circuit found that argument unpersuasive. They concluded that because the sclool district has a uniform policy of teaching in Englisl, there is no dis-

8. See Larry P. v. Riles, 343 F. Supp. 306 (N.D. Cal. 1972); Diana v. State Bd. of Educ., Civ. No. $70 B 7$ RFP (N.D. Cal. 1970); Hobson v. Hanseu, 269 F. Supp. 401 (D.D.C., 1967), aff'd en banc sub nom., Smuck v. Hobson, 408 F.2d 175 (D.C. Cir. 1969); Guadalupe Organization v. Tempe Elementary School Dist. No. 3, Civ. No. 71-435 (D. Ariz., Jan. 24, 1972).

See also Kirp, Schools as Sorters: The Constitutional and Policy Implications of Student Classification, 121 U. PA. L. Rev. 705, 760, nn. 270 \& 271 (1973). 
criminatory state action in the educational scheme, ${ }^{9}$ and, therefore, the demands of equal protection are satisfied. The majority in the court of appeals observed that "[e]very student brings to the starting line of his educational career, different advantages and disadvantages" which may affect his educational career "apart from any contribution by the school system."10 The implication of the court's statement is that as long as the schools have not affirmatively caused the particular handicap suffered by a student they need not take account of it; if all students receive the same treatment, the schools are not acting in a discriminatory fashion.

The question whether a school district's decision to ignore a remediable educational "handicap" suffered by a substantial percentage of the student population is so unjust as to violate constitutional guarantees is a difficult problem which will be discussed at length below. To assert that the state's sole constitutional responsibility is one of uniform treatment, however, is no answer to that problem. If Enghishspeaking children are given an effective public education while their non-Enghish-speaking classmates are not, only in the most formalistic sense may it be said that both groups are treated the same. To teach all subjects in a language which a child does not understand may deprive him of a meaningful education as effectively as denying him access to the classroom.

The harm that non-English-speaking children suffer does not just happen. The school district's decision to place non-English-speaking students in an educational environment which is not designed to educate them discriminates against them. Thus, the suggestion that there is no discrimination in Lau is deserving of no more judicial attention than, for example, the argument that there is no discrimination against the poor when the state establishes uniforn filing fees for candidates for public office. ${ }^{11}$ The real issue in Lau, as in the cases of uniforn fees, is not the fact of discrimination-which is readily apparentbut the constitutional gravity of that discrimination.

Plainly, not all discriminations by the state are violative of the equal protection clause; laws must make distinctions and most differences in treatment are justified. Since the judiciary is properly re-

9. There can be no doubt that there is state action; offering a program in English constitutes state action. The issue here is whether this state action is discriminatory.

10. Lau v. Nichols, 483 F.2d 791, 797 (9th Cir. 1973).

11. See Bullock v. Carter, 405 U.S. 134 (1972). Similarly, it cannot be denied that there is discrimination against newcomers to a state in the case of uniform durational residency requirements for welfare applicants. See Shapiro v. Thompson, 394 U.S. 618 (1969). See also Yu Cong Eng v. Trinidad, 271 U.S. 500 (1926), where a requirement that records be kept in English or Spanish was recognized to discriminate against Chinese-speaking pcople hiving in the Philippines. 
luctant to second-guess legislative or administrative reasons for the different treatment of one group as compared with another, the first rule of judicial application of the equal protection clause is that of deference. Conventionally, the constitutional test has been whether the state has a rational purpose for a particular classification. ${ }^{12}$ Since the fourteenth amendment was clearly designed to ensure that the states would not treat Blacks worse than whites because of race, however, the judicary has not been willing to defer to the states in cases involving racial classifications. This decisional rule is particularly important in those situations where it is not self-evident that the state action under review disables Blacks as compared with whites. Since 1954, at least, the United States Supreme Court has taken the position that when the state rule is explicitly based upon race, as when it treats Blacks and whites differently by assigning them to separate schools, ${ }^{13}$ or when a candidate's race is made to appear on the ballot, ${ }^{14}$ or when a special hurdle-voter rather than just legislative approval-is placed in front of open-occupancy ordimances, ${ }^{15}$ then the rule is to be strictly scrutinized by the judiciary. The Court seems to have concluded that since our experience indicates that rules dealing with race often serve invidious racial purposes, and different treatment of Blacks usually means inferior treatment, the state must justify its action with a showing that it is necessary to the furtherance of a compelling state interest. ${ }^{16}$ Few rules explicitly based on race can pass this stringent test. ${ }^{17}$

Blacks are not the only minority group that has won special judicial protection. An expanding list of suspect classifications includes those based on alienage, national ancestry, and illegitimacy. ${ }^{18}$ A history of invidious treatment of a group, its political impotence and vulnerability, and the inability of a nember of the group to free himself of the classifying trait all seem important factors in determining whether or not strict judicial scrutiny is warranted. The Court singles

12. See, e.g., Morey v. Doud, 354 U.S. 457 (1957); Williamson v. Lee Optical Co., 348 U.S. 483 (1955). See generally Tussman \& tenBroek, Equal Protection of the Laws, 37 CALIF. L. REv. 341 (1949).

13. Brown v. Board of Educ., 347 U.S. 483 (1954).

14. Anderson v. Martin, 375 U.S. 399 (1964).

15. Hunter v. Ericksou, 393 U.S. 385 (1969).

16. See Dunn v. Blumstein, 405 U.S. 330 (1972); Loving v. Virginia, 388 U.S. 1 (1967).

17. But see, e.g., Lee v. Washington, 390 U.S. 333 (1968) (per curiam) (separation of white and black prisoners) and De Funis v. Odegaard, 507 P.2d 1169 (1973) (preferential law school admission standards for minority students) cert. granted, 42 U.S.L.W. 3300 (U.S., Nov. 20, 1973).

18. See Gomez v. Perez, 93 S. Ct. 872 (1973) (illegitimacy); Weber v. Aetna Cas. \& Sur. Co., 406 U.S. 164 (1972) (illegitimacy); Graham v. Richardson, 403 U.S. 365, 372 (1971) (alieuage); Oyama v. California, 332 U.S. 633, 644-46 (1948) (national origin). See also San Antonio Independent School Dist. v. Rodriguez, 93 S. Ct. 1278, 1311 (1973) (Stewart, J., concurring). 
out these groups because they are in particular need of judicial assistance.

It is possible to argue in $\mathrm{Lau}$ that non-English-speaking individuals should be added to the list of those groups whose unequal treatInent invokes strict judicial scrutiny. The simpler arguinent, however, is that the discrimination in Lau involves an already recognized suspect classification. The school board's decision to conduct classes only in English discriminates against non-Enghish-speaking children on the basis of a trait which is linked both to their national origin and to their race. While the board's policy does not refer specifically to a particular race or nationality, such specificity is not a prerequisite to a finding of unconstitutional discrimination. In some cases, even though the state rule or action on its face is silent as to race, the Supreme Court has concluded that the harm to the minority group could only have been the product of a racial purpose. In the absence of a coinpelling reason for the discrimination, the Court will find such action unconstitutional. ${ }^{10}$ The Court might reacls this conclusion about a school district's "Enghish-only" policy as well.

On the other hand, the Supreine Court may view Lau as a case in which, although there is liarm to a racial-national-origin group, there is a plausible noninvidious explanation for that harm. Unfortunately, the Court has not made clear how such cases are to be analyzed-that is, whether they are to be treated as' race or nationalorigin cases, sinply as rational purpose cases, or as something in between. While the Court in Palmer $v$. Thompson ${ }^{20}$ suggested that the compelling state interest standard inay be invoked if racial effect is deinonstrated, it has not explained how inuch harm, or even what kind of harm inust be deinonstrated. ${ }^{21}$ The difficulty of the question

19. See, e.g., Gomillion v. Lightfoot, 364 U.S. 339 (1960) (unconstitutional scheme to disenfranchise blacks in Tuskegee, Alabama, by altering the city's boundaries along racial lines); Griffin v. County School Bd. of Prince Edward County, 377 U.S. 218 (1964) (unconstitutional system to avoid desegregation which included a combination of closed public schools and publicly funded tuition grants to white children who attend segregated private schools); Yick Wo v. Hopkins, 118 U.S. 356 (1886) (unconstitutional discrimination in the administration of a city ordinance regulating buildings suitable for operating laundries, which operated almost exclusively against Chinese persons).

20. 403 U.S. 217 (1971).

21. In Palmer, the Court held that the City of Jaekson, Mississippi, had not acted unconstitutionally in closing its public swimming pools even though this action had the effect of avoiding their desegregation. The majority opinion (per Justice Black) rejected the search for discriminatory motive as hopeless and concluded that this "effect" was not unconstitutional, because the city had no "affirmative duty" to operate swimming pools. Four justices, lowever, found unconstitutional racial motive or animus. Compare Brest, Palmer v. Thompson: An Approach to the Problem of Unconstitutional Legislative Motive, 1971 Sup. CT. REv. 95 (1971), with Ely, 
is illustrated by the problem of a neighborhood school-assignment plan to which no racial motive can be attached but which turns out to be racially isolative of Black and white students. The Court has thus far been unwilling to decide what to do im such a case; it debiberately avoided the issue in its decision last year in the Denver school segregation case. ${ }^{22}$ Although the Court has said that mere racial isolation arising out of a neighborhood school plan does not constitute a prohibited racial effect, might not the plan be unconstitutional if it is shown that Blacks, more than whites, are especially harmed, both educationally and psychologically, by racial isolation in schools?

Defendants in Lau rely on Jefferson $v$. Hackney, ${ }^{23}$ in which the Court rejected a challenge to a Texas rule that gave one class of welfare beneficiaries (families with dependent children-AFDC) a smaller proportion of federal guideline amounts than it gave to other classes (blind, disabled, and so forth). The AFDC class contamed $87 \%$ Blacks and Mexican-Americans; the other classes included $60 \%$ or more whites. The Jefferson opinion is unclear as to whether purpose or effect, or both, were crucial to the Court's decision. In any event, heavy rehance on Jefferson seeins inisplaced, because plaintiffs' case in Lau is in most respects much stronger than was that of plaintiffs in Jefferson. This point is illustrated by coinparing possible explanations for the result im Jefferson with the facts in Lau. Did plaintiffs lose in Jefferson because the percentage of racial minorities in the class was $87 \%$ rather than, say, $97 \%$ ? In Lau nearly $100 \%$ of the nonEnglish-speaking children may be identified by race or national-origin characteristics. Did the plaimtiffs lose in Jefferson because welfare recipients in the various categories were not seen as similarly situated? In Lau both those benefitted and those not benefitted by public education are children. Did the plaimtiffs lose in Jefferson because the court below made a finding that Texas authorities did not know the racial figures when establishing the benefit levels? In Lau the school district is fully aware of the inipact of its "English-only" policy. Did the plaintiffs lose in Jefferson because Blacks and Mexican-Americans were substantially represented (up to $40 \%$ ) in the other welfare categories? In this respect Lau is similar; inany Chinese (and Hispano-American) children speak Enghisl. ${ }^{24}$

Legislative and Administrative Motivation in Constitutional Law, 79 YALE L.J. 1205 (1970).

22. Keyes v. School Dist. No. 1, 93 S. Ct. 2686 (1973). The Court focused instead on the quantum of de jure segregation necessary in northern school districts to trigger a judicial requirement that the entire district be racially balanced.

See Goodman, De Facto School Segregation: A Constitutional and Empirical Analysis, 60 CALIF. L. Rev. 275 (1972).

23. 406 U.S. 535 (1972).

24. It is perhaps important that the tie between inability to speak Enghish and 
Perhaps neither purpose nor effect in itself is determinative of the question of the intensity of the judicial scrutiny which is appropriate in a given case. Perhaps the Court is simply engaging in a balancing process in these difficult cases. If the plaintiffs lost in Jefferson because the state's nonracial reason for the different treatment was more important than the amount of the harm they suffered, the plaintiffs in Lau, as discussed in Part IV, would appear to have a much greater chance of success in this regard. ${ }^{25}$ Because of the ambiguity of the Court's decision in such cases as Palmer and Jefferson, it is difficult to determine how the Court will go about deciding whether to treat Lau as a suspect classification case, and if it does not, what test will be applied in evaluating the state's action. Strict judicial scrutiny under the equal protection clause, lowever, is not limited to cases involving suspect classifications. The affected class also receives special protection when certain fundamental interests are at stake. The voting-rights cases are classic examples of this use of the clause. ${ }^{20}$ There is substantial ambiguity as to what rights can be considered fundamental under this approacl, although they certainly include those rights explicitly or implicitly guaranteed by the Constitution. If the Lau plaintiffs' interest in a ineaningful public education, which may be construed as affecting their constitutional right to freedoin of expression (particularly political expression), qualifies as fundamental, then the state will have to slow a compelling reason for its infringeinent.

Prior to the Courts 5-4 decision in San Antonio Independent School District $v$. Rodriguez, ${ }^{27}$ whicl involved a cliallenge to the constitutionality of the method by which states finance their public school

foreign origin seems stronger and more permanent than is the tie between race and AFDC welfare qualification as litigated in Jefferson, and, for that matter, the tie between racial isolation and neighborhood schools. That is, private action and other governmental policies realistically may ameliorate the over-representation of minority groups in the AFDC program and the housing patterns that give rise to racial isolation under a neighborhood assignment policy. By contrast, since Mexico, for example, quite clearly is not going to abandon Spanisl as its national tongue, it is hard to imagine how an "English-only" pohicy will ever cease to be a problem of "foreigners." The tie between language and race, as race is conventioually used, is not so intimate; there are, for example, at least some non-English-speaking, Italian-speaking children in the nation's schools.

25. Froun this perspective the case for Lau plaintiffs also seems stronger than that of the plaintiffs in Palmer, particularly because of the importance of the education interest and the unavailability of alternatives to public education for plaintiffs in Lau. Also, the decisious in Palmer and Jefferson were by no means unanimous: the split in each was 5-4. The minority in Jefferson avoided the constitutional questions, claiming the challenged treatment was a violation of the Social Security Act.

26. See Dunn v. Blunstein, 405 U.S. 330 (1973); Kramer v. Union Free School Dist., 395 U.S. 621 (1969); Reynolds v. Sims, 377 U.S. 533 (1964).

27. 93 S. Ct. 1278 (1973). 
systems, there was much debate about whether public education is a fundamental interest for the purposes of equal protection analysis. ${ }^{28}$ In Rodriguez, Texas's school-finance scheme was seen by the majority to afford each school district a minimum educational program, although the Court recognized that the wealthy districts had more expensive programs because they could draw on their greater taxable resources. Still, the majority was satisfied that the poor-district plaintiffs had sufficient resources so that they were not demed protection of fundamental interests. Had the Court concluded in Rodriguez that the plaintiffs there were denied fundamental interests, plaintiffs' case in Lau would be much stronger.

Yet Rodriguez neither dictates the outcome in Lau nor resolves the question of the constitutional importance of education. The decision in Rodriguez did not reach the question of whether children would be denied fundamental interests if they lack a minimum program, nor did it say what would constitute a minimum program. Moreover, although the actual plaintiffs in Rodriguez were nearly all MexicanAmericans, the suit's theory identified "poor" school districts as the injured class. Without entering here into the discussion of whether children of poor districts should be a class deserving of judicial solicitude, the Court's decision that they are not distinguishes Rodriguez from Lau.

Furthermore, even if the classification imvolved in Lau is not found suspect and the interest of the plaimtiffs in a public education is not considered fundamental, the possibility still exists that the Supreme Court will not simply defer to the school board's benign characterization of its scheme. Recent decisions of the Court suggest that in cases involving a substantial infringenent of an important (though less than fundamental) human right, the Court will deinand something more than a rational purpose for the state's action. ${ }^{28}$ The state's reason need not be conpelling, but it must be convincing. Just how convincing the state's explanation must be seems to depend to a great extent on the importance of the individual interest involved.

Regardless of the label which is attached to this last approach,

28. See J. Coons, W. Clune \& S. Sugarman, Private Wealth and Public Education (1970). Prior to Rodriguez, in a different context, two lower federal court cases seem to have approved the concept of a constitutionally protected right to a meaningful edncation. See Mills v. Board of Ednc., 348 F. Supp. 866 (D.D.C. 1972); P.A.R.C. v. Pennsylvania, 334 F. Supp. 1257 (E.D. Pa. 1972). For a full discussion of these cases, see Kirp, Buss \& Kuriloff, Legal Reform of Special Education: Empirical Studies and Procedural Proposals, 62 CaLrF. L. Rev. 40 (1974).

29. See Eisenstadt v. Baird, 405 U.S. 438 (1972). See also U.S.D.A. v. Moreno, 93 S. Ct. 2821 (1973); Reed v. Reed, 404 U.S. 71 (1971).

See generally Gunther, The Supreme Court, 1971 Term, Forward: In Search of Evolving Doctrine on a Changing Court: A Model for a Newer Equal Protection, 86 HARV. L. REv. 1 (1972). 
it is apparent that the Court is engaging in a balancing process. Indeed, it is perhaps inevitable that balancing is nccessary to dccide both the racial effect and interest abridged issues in difficult cases like Lau. From this perspective the separate constitutional doctrines coalesce imto one general inquiry: Is the deprivation of educational opportunity on the basis of a trait linked to race and national origin sufficiently severe to warrant judicial relief when balanced against the interests of the school district in providing instruction in English only?

The purpose of this section has been to note the manner in which various equal protection doctrines may be applied by the Supreme Court in Lau. The next section will discuss briefly two other legal theories to which the plaintiffs in Lau may have recourse. The balance of this Commentary, rather than arguing any one approach, will concentrate on the underlying interests and policy considerations which should inform the Court's decision: (1) Do non-English-speaking children need judicial help? (2) How badly are they hurt? (3) Why does the school district have an "English-only" policy and how strong is its interest in maintaining it? (4) Is this a judicially inanageable problem?

\section{III}

\section{OTHER LEGAL THEORIES}

The facts of Lau may also constitute a denial of due process or a violation of the Civil Rights Act of $1964 .{ }^{30}$ In due process terms it can be argued that compelling school children to attend public schools without affording them a meaningful education arbitrarily deprives them of their liberty. In Wyatt v. Stickney, ${ }^{31}$ which involved the confinement of persons to mental institutions which leeld them without treatment, the demal of personal liberty was ruled violative of due process.

One difficulty with this argument is that it may invite the school district to try to satisfy the requirenents of due process, not by providing the Lau plaintiffs with instruction, but by simply releasing them froin their unjustified confinement. The willingness of school districts to exclude low I.Q. children ${ }^{32}$ suggests that releasing non-Englishspeaking children miglit be politically possible. Since these children are not challenging the compulsory attendance laws, this is hardly the reinedy they seek.

30. 42 U.S.C. \$ $\$ 1971,1975 \mathrm{a}-75 d, 2000 \mathrm{a}$ to $2000 \mathrm{~h}-6$ (1970).

31. 325 F. Supp. 781 (N.D. Ala. 1971).

32. See Mills v. Board of Educ., 348 F. Supp. 866 (D.D.C. 1972) where plaintiffs successfully challenged such an exclusion, apparently on equal protection grounds. The district court ordered that the Washington, D.C. school system readmit all previously excluded children "regardless of the degree of the child's mental, physical or emotional disability or impairment." Id. at 878. 
In Wyatt the institutions having custody over patients with mental problems did not propose a release remedy; it appears unlikely that the district court would have allowed it in any case. Rather, the court ordered that plaintiff patients be provided with meaningful treatment. If release is not a viable alternative to unjustified confinement in the Lau context, then due process would appear to require that plaintiff schoolchildren also be afforded meaningful treatment. However, this presents a second difficulty. In deciding both the question of the adequacy of a release remedy in Lau and the question of what constitutes a meaningful education, the Court would seemingly have no clearer or different guidelines under substantive due process than under equal protection. ${ }^{33}$

It can also be argued that statutory provisions under Title VI of the Civil Rights Act of 1964 provide independent grounds for relief of petitioners in Lau. Section 601 of the Act provides:

No person in the United States shall, on the ground of race, color, or national origin, be excluded from participation, be denied the benefits of, or be subjected to discrimination under any program or activity receiving Federal financial assistance. ${ }^{34}$

This mandate has been fortified by regulations and guidelines issued by the Department of Health, Education and Welfare (HEW) pursuant to Section 602 of the Act. ${ }^{35}$ Soon after Lau was filed, specific guidelines were published ordering that affirmative steps be taken by school districts to deal with the language problems of non-Englisl1-speaking, national-origiu minority groups. ${ }^{36}$ Essentially the argument under the Civil Rights Act is that, by its failure to comply with the HEW guidelines, San Francisco has denied plaintiffs the benefits of the districts educational program on the grounds of race and national origin and should be enjoined, under section 601, froin further demial.

The difficult question raised by this argument is whether these guidelines provide an independent and broader basis for relief than is already provided by the fourteenth amendment's guarantee of equal protection. Both the district court and the court of appeals below apparently considered only the broader issue and concluded that the Act goes no further than the fourteenth anendment. The court of

33. See, e.g., the recent Supreme Court decisions in the abortion cases, Roe v. Wade, 410 U.S. 113 (1973), and Doe v. Bolton, 410 U.S. 179 (1973). Although decided on substantive due process grounds, the abortion cases could arguably have been decided on an equal protection theory, by requiring the state to justify the restrictions imposed on this type of medical procedure which were not imposed on other similar procedures.

34. 42 U.S.C. $\$ 2000 \mathrm{~d}(1970)$.

35. See 45 C.F.R. $\& 80.3$ (1972) (administrative regulations).

36. For the text of the guideline, see note 44 infra. 
appeals summarily dismissed plaintiffs' claims under Title VI after denying their constitutional claim. ${ }^{37}$

It is certainly arguable that Congress intended Title VI to go no further than the equal protection clause, although the United States, in its aimicus brief to the Suprene Court in Lau, urges that Title VI standards are independent of and not necessarily coincident with the fourteenth amendment. ${ }^{38}$ Specifically, the Urited States argues that HEW guidelines under section 602 properly carry out section 601 standards. It is also open to question whether private actions are contemplated for violations of Title VI, although a number of lower courts have concluded that section 601 inay be enforced privately. ${ }^{30}$ Further, the nuain thrust of the title is the cutoff of federal funds and section 602 deals exclusively with that remedy. Thus, a school district might argue in its defense that even if Title VI were privately enforceable, the sole reinedy for a violation is the discontinuance of federal funding. Alternatively, if it appears that section 601 is privately enforceable by injunction, the district might assert that only fourteenth amendment standards govern the reach of section 601 and not administrative regulations promulgated under section 602 .

If, as this Commentary concludes, equal protection demands what HEW's section 602 guidelines require, nany of the complexities of the Title VI approach are avoided and the same result is reached with the fourteenth ainendment argument. On the other hand, if Title VI standards are truly independent of the fourteenth amendment, an argument based on the Act enjoys the advantage of allowing the Court to avoid a constitutional confrontation by deciding the case on statutory grounds, whether or not Title VI is broader than the fourteenth amendment. Thus, the argument that a school district's "English-only" policy violates the Civil Riglits Act of 1964 may prove an attractive alternative to the equal protection approach.

\section{IV \\ Policy CONSIDERATIONS \\ A. The Need of Non-English-Speaking Children for Special Judicial Protection}

Plaintiffs in Lau belong to a class whose characteristics peculiarly qualify it for special judicial protecton. It is apparent that children

37. Lau v. Nichols, 483 F.2d 791, 794 n.6 (9th Cir. 1973).

38. The United States supported petitioners' claims in the Ninth Circuit and in the U.S. Supreme Court on both Title VI and fourteenth amendmeut grounds.

39. See, e.g., Bossier Parish School Bd. v. Lemon, 370 F.2d 847 (5th Cir.), cert. denied, 388 U.S. 911 (1967); Natonabah v. Board of Educ., 355 F. Supp. 716 (D.N.M. 1973). 
as a class are politically powerless, and it is unreasonable to expect their parents to bring about the needed educational changes througli the political process. This conclusion is supported by current political realities and historic discriminatory practices. Nearly all nonEnglish-speaking children come from non-Enghsh-speaking homes. ${ }^{40}$ While this does not invariably mean that their parents are recent immigrants or aliens, they almost certainly will be among those conventionally viewed by American society as "foreign." 41 It is also true that in America today nearly all non-English-speaking families are minority families. ${ }^{42}$ The need for judicial intervention to protect "foreigners" and racial minorities from disadvantageous treatment by the state is well understood. The politically isolated status of families of nonEnglish-speaking children is aggravated by the parents' lack of fluency in the dominant language.

One slould not be misled as to the political power of this group because Congress has provided some financial inventives for districts which lelp these children ${ }^{43}$ and because HEW's Office of Civil Rights promulgated guidelines in 1970 calling for programs to be adopted for their benefit.44 San Francisco's experience illustrates the inadequacy of these federal efforts. Although at the time Lau was filed federal funds were being used for special programs for Chimesespeaking students, today many Chinese-speaking students still receive no help in Englislr. ${ }^{45}$ Also, the HEW guidelines mandating that af-

40. While some children from English-speaking homes cannot speak English when they enter school because of physical, mental, or psychological disabilities, they are rather isolated cases. The record in Lau provides no statistics.

41. For an example of American treatment of "foreigners" within this country, see Meyer v. Nebraska, 262 U.S. 390 (1923). After World War I, people looked upon those who spoke German as dangerous foreigners, and tried to prevent German froin being taught or spoken in the schools. It is also interesting that Puerto Ricans are typically viewed as "foreigners," although they do not come from a foreign country.

42. Most non-English-speaking children in the United States speak Spamish, and the United States Supreme Court has recognized Hispanic people as a distinct "racial" group. See Keyes v. School Dist. No. 1, 93 S. Ct. 2686 (1973); White v. Regester, 93 S. Ct. 2332 (1973).

43. Federal funds for bilingual programs are available under the Bilingual Education Act, 20 U.S.C. $\$ 880 \mathrm{~b}$ to b-5 (1970), and for bicultural programs under the Education Amendments of 1972, Pub. L. No. 92-318, $\$$ 504(a), 86 Stat. 346.

44. HEW guidelines formulated pursuant to Title VI of the Civil Rights Act of 1964 provide:

Where inability to speak and understand the English language excludes national origin-minority children from effective participation in the education program offered by a school district, the district must take affrmative steps to rectify the language deficiency in order to open its instructional program to these students.

35 Fed. Reg. $\$ 11595$, Iuly 18, 1970. See also 45 C.F.R. $\$ 80.3$ (1970).

45. The current status of the 1,790 students composing the Lau plaintiff class is unknown. 
firmative steps be taken to serve the needs of non-English-speaking pupils have not been enforced in San Francisco. Finally, there are no reported cases of federal fund cutoffs for noncompliance with the guidelines. The inadequacy of these federal efforts further reveals the political weakness of the victims of an "English-only" policy.

Just as passage of the Civil Rights Act of 1964 and the availability of substantial federal aid to desegregating school districts ${ }^{40}$ have not struck racially isolated schools from the agenda of judicial priorities, federal policy statements should not preclude relief in Lau. Indeed, if our experience with school segregation is an apt guide, non-Englislspeaking students will not be able to count on sustained federal efforts to carry out congressional pohicy. ${ }^{47}$

Self-help also will not suffice in this situation. It is unreasonable to expect non-English-speaking children themselves to be responsible for ensuring that they speak English by the time they start school. Furthermore, regardless of how one feels about parental duties, it seems unfair to pumsh children for the maction of their parents, ${ }^{48}$ particularly when their parents do not speak Englisl. As the parents are likely to be poor, they cannot be expected to provide their children with private English tutors or private education in the child's native tongue until he learns English.

Finally, like our long-range expectation of distinct racial groups, the existence of substantial numbers of non-English-speaking children is likely to continue im the future. Thus, unless we require proof of ability to speak English as a condition of immigration to this country, this classification is not going to disappear. For these reasons, judicial relief from state action which harms non-English-speaking children is particularly appropriate.

\section{B. The Harm Suffered by Non-English-Speaking School Children.}

A school district's "Enghish-only" policy has severe stigmatizing and isolating effects on non-English-speaking children and amounts

46. See, e.g., 20 U.S.C. $\$ \$ 1601-19$.

47. See Adams v. Richardson, 356 F. Supp. 92 (D.D.C.), aff'd, 480 F.2d 1159 (D.C. Cir. 1973) (per curiam).

48. See Chandler v. South Bend Community School Corp., Civ. No. 71 S 51 (N.D. Ind., Aug. 26, 1971), which involved the refusal of parents to pay certain school fees or sign an "inability to pay" form, resulting in suspension or other discriminatory action being taken by the school against students. The court held this practice violated the children's rights under the equal protection clause (slip opinion at 7).

Similarly, the doctrine of imputed contributory negligence, punishing a child for 
to an absolute denial of a neaningful educational program for a substantial portion of their lives.

\section{Psychological Harm}

Although definitive social science evidence of the psychological harm visited upon the students is unavailable, there is good reason to assume that non-Enghish-speaking children who are left out of classrooni programs are stigmatized and made to feel inferior. These children are not treated as might be an American professor's children temporarily enrolled in Italian schools while the family spends a sabbatical year in Florence. The non-English-speaking child permanently assigned to American "English-only" schools is branded by his inability to comprehend and respond to the educational program.

Lacking the sophistication to damn the system, the child who is excluded nray view himself as wrong, not wronged. If he cannot participate in the program as he sees other children doing, he may well reason that he is to blame. Surely if the Ninth Circuit in Lau can imply that the child is at fault, ${ }^{49}$ it is not too much to imagine that the school itself conveys a like message to the child. Moreover, as with the stigina associated with racial separation in Brown, it is reasonable to assume that the early effects on non-Enghish-speaking children will not soon dissipate.

To be sure, it may also be both stigmatizing and isolating to be taken aside and taught English when everybody else already knows how to speak English. But this separation is intended to be temporary and hence may be reasonably expected to be far less severe than the harm the district perpetuates by offering no such help. While a district may come forward with evidence to the contrary, in Lau San Francisco has not. Put in conventional terms, Lau should be treated like Brown in the sense that psychological harm should be presumed. As in Brown, when we know that the state policy is directed against a minority group, absent evidence to the contrary the Court's sense of the harm rather than its "proof" slould be sufficient. While it is true that the school district lias a strong interest in seeing that a national-origin group is not segregated, this interest ought not be interposed to close off help to Chinese- or Spanish-speaking children. Physical integration for its own sake, when effective classroom isolation results, is not what the equal protection clause intends. ${ }^{50}$

actions of his parent, has been widely rejected by statute or decision. W. Prosser, THE LAW OF TORTS $\$ 74$ at 490 (4th ed. 1971).

49. 483 F.2d 791 (9th Cir. 1973).

50. See Keyes v. School Dist. No. 1, 93 S. Ct. 2686, 2701-20 (1973) (Powell, J., concurring in part aud dissenting in part), 


\section{Educational Harm}

In addition to suffering enduring psychological harm, Lau plaintiffs are not receiving meaningful schooling either in terms of input or output so long as they do not speak Enghish. With regard to input, to argue that substantial sums are spent on these children distorts reality. Although they may receive costly baby-sitting, this certainly does not constitute an educational program. As for output, it is unknown, for example, whether these children will fare as poorly on achievement tests during the time that they do not speak English as would children who were barred at the classroom door. The record in Lau does not directly address this question. Still, one can be reasonably confident that at the time they filed their lawsuit, Lau plaintiffs had learned at school painfully little that could be called positive.

It also seems clear, although agam the Lau record is not very revealing, that in the absence of special help, the inability to speak English persists for a substantial period. ${ }^{51}$ Ironically, under present circumstances the presence in the same school and classroom of numbers of children who cannot speak English but are fluent in another common tongue (for example, Chinese or Spanisli) inay contribute to a prolongation of the period. The large numbers create both the compelling need and a very practical basis for special help.

The Supreme Court has rendered decisions supporting the idea that at least a minimal education is absolutely essential to the social, economic, and political well-bemg of an individual in American society. ${ }^{52}$ Without basic linguistic skills, an individual will be unable to interact with the community-at-large, unable to obtain a job which is more than menial, and unable to express himself properly and participate adequately in the political process. Children from poor nonEnglish-speaking homes are particularly rehant on the state for this preparation. Hence, as discussed earlier, if such children are unnecessarily denied neaningful public schooling, the educational deprivation alone might rise to the level of a constitutional violation. ${ }^{58}$ Indeed, if deprivation is neeasured by input alone, the facts in Lau might well establish such a constitutional violation.

Yet in output terms it is difficult to argue that a severe and permanent deprivation of a minimum education exists in the Lau case, at least from the Lau record. Common sense tells us that it would be naive to think that all Lau plaintiffs will never learn Enghish or anything else important in scliool. Many plainly will. Indeed, simce

51. See Petitioners' Brief for Certiorari, at A-114, Lau v. Nichols, $93 \mathrm{~S}$. Ct. 2786 (1973).

52. See Wisconsin v. Yoder, 406 U.S. 205 (1972); Brown v. Board of Educ., 347 U.S. 483 (1954); Pierce v. Society of Sisters, 268 U.S. 510 (1925).

53. See text accompanying notes $26-29$ supra. 
the lawsuit was first brought nearly four years ago, some or many of them probably have developed reasonable fluency in Enlgish by now.

This does not mean, however, that the long run educational injury to Lau plaintiffs is trivial. Even if the "Enghish-only" policy is not a denial of a minimum education, equal educational opportunity is surely denied. That is, the psychological harm they experience and the educational deprivation they suffer, as compared to other children, have a lasting debilitating impact on the school careers of non-Englishspeaking children. Testimony as to the high illiteracy and drop-out rates of non-Englisli-speaking students ${ }^{54}$ reflects the severity of early educational harm. Even if language problems are not the sole cause of long-term lower achievement of children who start out school speaking no Enghish, it is unimaginable that early language difficulty is not an important contributing factor. In other words, the sclool failsboth by its conscious academic policies and their effects-to tap the individual potential of these students.

\section{Economic and Political Harm}

Focusing on long-run economic and pohitical impact, it may be argued that if children do not learn to speak Enghisl they cannot be expected as adults to participate in and comprehend political debate or deal with the English-language ballot. ${ }^{55}$ Although it is difficult to argue that the school district's "Enghish-only" pohicy denies most non-English-speaking children first amendment and voting rights, still those who remain illiterate may be effectively denied these rights.

As for those who will eventually learn enough English to vote and engage in political discourse, our instincts tell us that their participation will be less than that of children not so educationally disadvantaged. Moreover, it probably could be convincingly demonstrated, for instance, that the Lau plaintiffs as a group will vote less than their English-speaking classmates, although the reasons for this might include factors other than English-language disabilities.

54. See Montoya, Bilingual-Bicultural Education: Making Equal Educational Opportunities Available to National Origin Minority Students, 61 GEO. L.J. 991, 992-993 (1973). See also Hearings on S. 428 Before the Special Subcomm. on Bilingual Education of the Senate Comm. on Labor and Public Welfare, 90th Cong., 1st Sess., ser. 18, pt. 1, at 33-37 (1967).

55. Some states, such as California, have legislation providing election aids such as facsimile ballots im second languages be made available to secure wider participation by non-English-speaking voters. See, e.g., CAL. Elec. CODE $\$ 14201.5$, .6 (West Supp., 1973) (county clerk may provide facsimile ballots in languages other than English where need for same is perceived). But effective political participation requires more than being able to read a ballot and operate a voting machine. Attacking the problem of political alienation by eliminating linguistic exclusion in the schools offers a greater lope of securing informed and motivated political participation in the long run. 
Specifying the economic harm to the Lau plaintiffs is equally difficult. While it would be difficult, for instance, to convince anyone on the present evidence that most of the Lau plaintiffs will wind up on the welfare rolls, many probably will. And despite the doubts that have been recently showered on the significance of education for lifetime incoine, ${ }^{56}$ some credible showing surely could be made as to the relatively bleak career prospects for children who grow up with English-languge problems as opposed to those who do not.

\section{The School District's Interests in Maintaining an "English-Only" Program}

There are several possible justifications for a school district's failure to integrate non-English-speaking children into its educational program. The first is that it is not the school's job to teach children to speak Englisl; that responsibility has always resided, and should continue to reside, in the family. The weakness of this argument is its failure to appreciate that it is the job of the school to educate children. If the school offers a program which is meaningless to some students, then it is not performing its proper educational function. It is certainly unconvincing for a school systein which teaches German, French, and Spanish, and which offers English im all twelve grades, to assert that it is not institutionally qualified to teach English to nonEnglish-speaking children. Compulsory attendance grew out of a societal assumption about the greater competence and rehability which schools, as compared with parents, have in the teaching of the young. It is inconsistent with the responsibility this country has reposed in the public education system for the latter to try to avoid the obligation on the ground that adequate preparation in English is the family's job.

Moreaver, allowing the schools such a limited view of their role is incoinpatible with the flexibility which it is reasonable to expect of the education process. Assuming that all children come to school in exactly the same condition, needing the same treatment, conflicts with the reality of how schools actually operate. Public schools normally offer a wide range of special educational programs to treat different (individual) needs, including programs for the emotionally disturbed, the educable retarded, the physically handicapped, and the educationally liandicapped or gifted. ${ }^{57}$

The school district's unwillingness to teach English to non-English-speaking students inay mask a frightening smugness which suggests that since the children of immigrants have always "managed"

56. See, e.g., C. JeNCKS, INEQUALITY (1972).

57. See, e.g., CAL. EdUC. CODE $\$ \$ 6750-6763$ (educationally handicapped); $\$ \S$ 6801-6855 (physically handicapped); $§ ~ 6901-6920$ (mentally retarded). 
in past years despite their language disability they should continue to do so. Given a sufficient number of generations, most people will be assimilated. Yet the rights of the current generation of children should not be sacrificed in the name of that eventuality. The patience and long hardship that is demanded is inappropriate in today's world. Not only is education considered more important now than it has ever been in the past, but as a nation we are properly more intolerant of delays in eliminating injustices to minorities, particularly children, than we have been in the past.

A second possible justification for the scliool district's "Englislonly" policy is that it is unnecessary specifically to teach non-Englishspeaking students to speak English because they learn the language just as quickly when they are ignored. The assumption would be that the children are engaged in a peculiar sort of "total immersion" program. While this is not incomprelensible, neither is it very credible; if true, it would be a very sad cominentary on school effectiveness. In any event, it is an argument on whicl the school district should have the burden of proof. Since both Congress and HEW have concluded that affirmative steps are needed, there should be at least a rebuttable presumption that English instruction would be helpful. ${ }^{58}$

A third argument for the school district's position is that the district does not have adequate monetary resources to take affirmative steps to aid non-Englisl-speaking children. At present, lowever, the school district is wasting inoney by having these students in programs they cannot understand. Such money would be far better employed teaching thein English. Since the San Francisco scliool district has classrooins full of non-English-speaking students among its pupils, a change in the district's Enghish-only policy certainly would not be unreasonably inefficient. Such a change would, lowever, require the retraining of some present teachers or the hiring of new personnel to teach non-English-speaking classes. This would appear to go to the crux of the district's economic concerns. In general, school districts already have on their payrolls people who are not trained to teach non-English-speaking children and who are not anxious to take on what they see as added responsibility. School administrators feel politically constrained neither to replace nor to force retraining of such teachers. ${ }^{\text {so }}$ Declining enrollment in many districts, better salaries, and the changed character of our teaching force mean that fewer positions are opening up through attrition. Hence, the districts view the prob-

58. For an analogous use of a presumption, see Keyes v. School Dist. No. 1, 93 S. Ct. 2686 at 2697 (1973), and Griggs v. Duke Power Co., 401 U.S. 424 (1971).

59. In addition, the school district's powers with respect to many of its teachers are practically limited by the existing tenure system. 
lem of dealing with non-English-speaking children as a matter of more money for hiring English-teaching or bilingual specialists.

In response to this argument, courts need not imsist that teachers be replaced. School districts currently have taxing power and resources which they employ to educate English-speaking children. If they do not wish to reallocate priorities by interfering with "rights" of teacliers; they should be required to raise more money. Putting teachers' concerns before childrens' educational needs reflects the kind of official callousness toward minorities which the Constitution should not be construed to tolerate.

As a variation on its economic argument, the school district might assert that the cost of doing anything very helpful for non-Englishspeaking children is unreasonably high. This could inean either that taxpayers would be unreasonably burdened, or that other children would be unreasonably harmed by having resources shifted away from them, or that teaching non-Englisl-speaking children is peculiarly inefficient. Were this argument something that the school district could prove rather than inerely assert, it might be effective. In fact, however, teaching non-English-speaking children does not seem to be a terribly expensive proposition. Clearly, it does not involve the same costs as might be imvolved in teaching autistic children, for example. There is no evidence on cost in the Lau record; but in view of the imjury to petitioners and the contrary assumptions of Congress, the burden of proof once more should be on the school district. ${ }^{60}$

Finally, a school district might argue that an "Enghish-only" policy fosters the country's interest in a single national tongue. That interest, however, is frustrated, not furthered, by failing to teach English to children who speak other tongues. While it may make the San Francisco public scliools unwilling to teacl the Lau petitioners exclusively in Chinese, it clearly does not preclude the use of an ESL program. Moreover, althougli the importance of liaving all Americans fluent in Enghish is not disputed, this does not necessarily require the suppression of other languages. Language is seen by many as critical to the preservation of some non-white cultures. "Bilingual-bicultural" programs are designed to ensure that minority children may participate in the dominant culture without being stripped of their own ethnic backgrounds. The Constitution may not prefer bilingual training to ESL as an approach to the education of non-Enghish-speaking students,

60. Of course, a district with one Chinese-speaking child would be expected to offer a different kind of help and wonld face different cost problems than one with 1,800 as in San Francisco. Again, these are matters which should be argued by the defense. The pohicy which assumes that children speak Enghish when they start school cannot be justified by arguing that it stimulates parents to teach their children English when those who need the stimnlation are, in fact, ill equipped to respond to it. 
but the appeal of the bilingual method urges special caution in evaluating the state's interest in a single national tongue. In any event, this last claim is more appropriately addressed to proposed remedies for the discrimination in Lau than to the merits of the case.

\section{Judicial Manageability}

Even if the Court were convinced that non-English-speaking children are deprived of a meaningful public education and that the state interest in the present discrimination is weak, at least two issues remain. First, is there a judicially manageable standard to govern the remedy chosen by the Court which is neither too stringent nor an empty gesture? Second, what will be the effect of the decision in other areas where the state has failed to provide for an Englisl-language disability?

Even if it is clear that plaintiffs in Lau are currently receiving no meaningful education, how will the Court determine when they are? It is submitted that the relevant constitutional principle for cases like this should be that scliool districts must take affirmative steps to integrate all children into their educational program. The emplrasis should be on opportunity rather than output. Too many inseparable factors affect the educational, political, psycliological, or economic results of a school district's program for the judiciary profitably to employ a "performance" standard. ${ }^{61}$

Nevertheless, an "opportunity" standard is not self-explanatory, and some attention must be given to low representatives of non-Englislr-speaking children, scliool districts, and ultimately federal courts, are to resolve disputes which are certain to arise over whether the school district's affirmative steps are adequate. The proposed test is whether the school district, in liglit of all the facts and circumstances, is making a reasonable effort to educate non-English-speaking children when compared with the effort made for those wlo do speak English. A reasonableness standard is one which people understand. It also is a familiar judicial standard, in both common law and constitutional litigation. As with the prohibition against unreasonable searclies and seizures, manageable rules can be worked out on a case-by-case basis. For example, the lialf-way measure of providing Englisli imstruction to some non-English-speaking children in the district but not to others would not, in the absence of special circumstances, constitute affirmative steps-that is, it would not be a reasonable effort to educate the ignored children.

61. Suits which attack school-finance systems and demand resource distribution according to students' needs face the same problem. See McInnis v. Shapiro, 293 F. Supp. 327 (N.D. Ill. 1968), aff'd mem., sub nom. McInnis v. Ogilvie, 394 U.S. 322 (1969). 
It bears repeating, however, that the reasonableness standard would not include any specific pedagogic content. The school would not be ordered to do whatever is necessary to ensure that formerly non-English-speaking children do as well on standard school-achievement tests as do children who come from English-speaking homes. ${ }^{02}$ Likewise, the school would not be required to guarantee that all nonEnglish-speaking children are in fact speaking English by a certain date. The school would only be required to afford non-English-speaking students a reasonable opportumity to learn. Once the school district has a program reasonably calculated to educate all of its children, unless it can be proven a sham so far as non-English-speaking children are concerned, a district court should defer to the professional judgment of the district as to the specifics of the program.

So long as the power of the federal courts remains available to deal with unreasonable school districts, it is fair to rely largely on the political process to stimulate program developments. It should be noted, however, that a district's actions would more likely be regarded as reasonable if the district involved representatives of non-Englishspeaking children in the planning of their educational program. ${ }^{63}$

While an "output" standard may be unworkable for the Court, educational results are the ultimate goal of plaintiffs in Lau. What results miglit they expect? If the proposed constitutional standard is adopted and school districts are required to provide instruction for nonEnglish-speaking students, most should learn English fairly quickly. At least to the extent that the current achievement gap is attributable to language handicaps, they slould not remain very far behind their classinates. By giving attention to the language problems of non-English-speaking children, a district also may come to appreciate better these children's other educational handicaps, many of which are suffered

62. But cf. Serna v. Portales Municipal School, 351 F. Supp. 1279 (D.N.M. 1972), where the court apparently concluded that because Spanish-speaking students had poorer results in standardized achievement tests, they were denied their constitutional rights. It would seem that this denial will continue until the scores of Spanish and English speaking students are equalized. Given the wide variety of factors which affect achievement test scores, this standard may prove extremely difficult for a school district to meet; and, in terms of judicial intrusiveness, the standard is certainly questionable.

63. An analogous function is intended for Parent Advisory Councils established under Title I of the Elementary and Secondary Education Act of 1965 . See 36 Fed. Reg. $\$ 116.17(0)$ (Oct. 14, 1971): "Parental involvement at the local level is deemed to be an important means of increasing the effectiveness of programs under Title I of the Act."

An alternative to the reasonableness standard is good faith. Since this test is subjective, courts are often pressed to look to objective measures which may turn good faith into the equivalent of the reasonableness test anyway. See, e.g., Green v. County School Board of New Kent County, 391 U.S. 430 (1968). 
by poor children generally. Lau, however, would not in itself provide a basis for ordering them to be remedied. Compensation for these handicaps will take other hitigation, or legislation. ${ }^{64}$

Vindication of the constitutional rights of non-English-speaking school children ought not be thwarted by fears of an uncontrollable flood of litigation brought by non-English-speaking persons in other areas. In the long run, a decision in favor of non-Englisil-speaking schoolchildren will limit the pressure for judicial rehef in other areas. Insisting that the public schools take responsibility for teaching English to young students is the single most promising step in ensuring their access to rights and liberties currently denied many people because of language barriers. In the meantime, when government action operates to imjure persons who do not speak Enghish, a careful examination of the interests involved will be required in eacli case. ${ }^{65}$

\section{CONCLUSTON}

Through Lau, non-English-speaking minorities and their advocates seek a shift in the present political balance that places the needs of this group far down the list of educational priorities of most school

64. E.g., Title I of the Elementary and Secondary Education Act of 1965, 20 U.S.C. $\S \S 241 \mathrm{a}-\mathrm{m}$ (1970). The title provides funds to compensate for low achievement due to poverty. California has a similar compensatory education program under which a district receives money in part because of the concentration of non-Englishspeaking children. See CAI. Educ. CODE, § 6499.232(a) (West, 1973).

65. The Constitution, for example, may require that a non-English-speaking criminal defendant have the service of an interpreter at a trial [Cf. Negron v. New York, 434 F.2d 386 (2d Cir. 1970)] or that a non-English-speaking voter be able to bring an interpreter into the voting booth with him [Cf. Puerto Rican Organization for Political Action v. Kusper, 350 F. Supp. 606 (N.D. Ill. 1972); Garza v. Smith, 320 F. Supp. 131 (W.D. Tex. 1970)].

If, however, the booklet given to prospective drivers containing the "rules of the road" were printed only in English, this would not seem to rise to the level of a constitutioual violation. On the other hand, if the examination needed to obtain the driving license is given only in English, then the constitutional outcome of a challenge to that practice would depend, among other things, upon the fact that adults are involved, and upon both low important the Court thinks it is to have a driving license, and low reasonable it is to require an understanding of English as a precondition to driving in the interest of the safety of others. Cf. Bell v. Burson, 402 U.S. 535 (1971).

In Carmona v. Sheffield, 475 F.2d 738 (9th Cir. 1973), the Ninth Circuit held that furnishing all notices for unemployment insurance benefits in English did not deny Spanish-speaking persons due process of law; and in Guerrero v. Carlson, 9 Cal. 3d 808, 512 P.2d 833, 109 Cal. Rptr. 201 (1973), cert. denied, 42 U.S.I.W. (Jan. - , 1974), the California Supreme Court rejected plaintiff's contention that due process requires the state to provide welfare notices in Spanish to persons literate in Spanish only. Without considering here the merits of the Guerrero decision, it is important to note that the decision rested on the assumption that self-help is a feasible alternative for welfare recipients. This is simply not an effective remedy for plaintiffs in Lau. See generally Comment, Citado a Comparecer: Due Process: Is Mailed Notice in English Constitutionally Sufficient?, 61 CaIIr. L. Rev. 1395 (1973). 
districts. If representatives of non-English-speaking children have a voice in the design of the district's program, an atmosphere can be created which will be conducive to a re-ordering of priorities. Because they lack a politically strong constituency, however, representatives of non-English-speaking children must have the power and coinmitment of the courts behind them.

A victory in Lau may mean that courts will be forced to deal with efforts to circumvent their orders, just as the enforcement of Brown has required judicial intervention to prevent, for example, segregated classes within a desegregated school district, the firing or demoting of black teachers and principals following the desegregation of a school system, and racially biased student-discipline decisions. In the case of non-Englisl-speaking children, the courts will have to be on guard against district practices which involve the long-term separation of these children from the regular classroom, during which time they are given decidedly second-class schooling.

Moreover, the courts may face opposition to some plans which might be adopted to remedy the Lau problem. The thrust of Lau, like Brown, is integrative and assimilative. Just as some Black leaders today disclaim Brown and call for quality, Black-run, nonintegrated (neighborhood) scliools, there may be some minority group leaders who will view a victory for the Lau plaintiffs as antithetical to the preservation of ethnic culture. Yet a decision in favor of the plamtiffs in Lau need not, and should not, bring about a de-emphasis of ethnic culture. Districts may employ bilingual-bicultural programs in the education of non-English-speaking children.

To argue that bilingual-bicultural programs are constitutionally required, however, is another matter. From what is known today, it is likely that intensive Englisl instruction will succeed in teaching children to speak English and hence would satisfy the constitutional interests discussed in this Commentary. To the extent that English-based American publc education threatens cultural identity, and to the extent that other factors besides language stand in the way of a child's educational progress, it is submitted that additional legal theories will be necessary to vindicate the child's interests. In the meantime, it is important that the opportunity presented by Lau for non-English-speaking children to obtain a meaningful education through special English instruction not be bypassed because of this concern about a more distant and difficult goal.

Children come to school expecting to learn. Society operates on the premise that they do learn. The public education system should not be permitted to turn a remediable educational "handicap" based upon race and national origin into a permanent disability. 